\title{
Customer satisfaction and brand equity
}

\author{
Anna Torres ${ }^{\mathrm{a}, *, 1}$, Josep A. Tribó ${ }^{\mathrm{b}}$ \\ ${ }^{a}$ Universitat Pompeu Fabra, C/ Ramon Trias Fargas, 25-27, 08005 Bareetona, Spain \\ b Carlos III University, C/ Madrid, 126, 28903 Getafe (Madrid), Spain
}

\section{A B S T R A C T}

The study here examines the interaction between shareholder value and customer satisfaction, as well as the impact on a firm's brand equity. Customer satisfaction may have a positive effect on brand equity, except when managers show excessive customer orientation, in which case the effect is negative because of reductions in shareholder value. The empirical analysis uses incomplete panel data pertaining to 69 firms from 11 nations during the period 2002-2005 and supports the theoretical contentions. This result warns of

Keywords:

Corporate social responsibility the perverse effect on brand equity of implementing policies focused exclusively on satisfying customers at

Brand equity

Shareholders' commitment

Customer loyalty

\section{Introduction}

Drawing on Mintzberg's (1983) work, different theorists stress that managers should adopt a broad perspective that integrates not only customers but also other stakeholders' interests and values to define a successful firm strategy (Greenley et al., 2005; Miller and Lewis, 1991). According to this stakeholder view, a firm should adopt different positions depending on the importance assigned to the interests of different stakeholders.

Mintzberg (1983) also suggests that stakeholders with more power should receive greater "care". This vision then prompts the descriptive approach associated with stakeholder theory (Jawahar and McLaughlin, 2001; Mitchell et al., 1997), which indicates that the degree to which managers prioritize competing stakeholders' claims (i.e., salience) relates positively to the stakeholder attributes of power, legitimacy, and urgency. An extreme case of this line of research states that customers should receive all power, so managers should focus on satisfying the needs of these stakeholders (Anderson, 1982). Greenlay and Foxall (1998) similarly establish customer orientation as the basis of any policy addressed to employees or stakeholder-like competitors.

In contrast, Miller and Lewis (1991) defend a balance between the values and needs of different stakeholders, without prioritizing any of them. Luk et al. (2005) reveal that the combined effects of different stakeholder orientations constitute the essence of a firm's competitive advantage. In particular, these authors show that the interaction among customer orientation, competition orientation, and employee

\footnotetext{
* Corresponding author.

E-mail addresses: ann.torres@upf.edu (A. Torres), joatribo@emp.uc3m.es (J.A. Tribó).

1 Affiliated to the Barcelona CSE.
}

orientation explains the success of service firms in China. Aupperle (1984) further links social practices involving all stakeholders to positive financial performance. Satisfied stakeholders provide different types of intangible resources to a firm, which enhances its value (Blumenthal and Bergstrom, 2003) and therefore its brand equity (Keller, 1993). This view provides the basis for instrumental theory (Donaldson and Preston, 1995; Jones, 1995), which argues that corporate responsibility performance positively influences financial performance and has a positive overall effect on a firm's brand equity value.

Recent attention also centers on the idea of connecting social and financial performance to brand equity (BE), defined as the marketing effects or outcomes that accrue to a product with its brand name compared with those that would accrue if the same product did not have that brand name (i.e. Ailawadi et al, 2003). On the social performance, for example, Mühlbacher et al. (2006) define brands as complex social phenomena in which different stakeholders play roles to create $\mathrm{BE}$. On the financial performance, the slack resources hypothesis confirms the connection between financial results and a firm's BE (Waddock and Graves, 1997). Stronger financial performance leads to a surplus of resources that provide firms with the financial wherewithal to satisfy their stakeholders, which in turn improves the firm's BE (Kraft and Hage, 1990; McGuire et al., 1988; Preston et al., 1991).

The study in the present report adopts an integrative view and recognizes the relevance of shareholder value (SV), as well as corporate social performance (CSP) involving all stakeholders in general and customer satisfaction (CS) in particular for the creation of BE. Specifically, this article proposes two claims. First, SV partially mediates the connection from CS to the creation of BE. Second, through this mediation, an inverted U-shaped relationship exists 
between CS and BE. A manager who focuses on satisfying only the most salient stakeholders (i.e., customers) and neglects remaining stakeholders will cause the firm's SV to erode and with that its BE. This approach contrasts with the traditional literature that suggests an unambiguous positive effect of CS on value generation. Anderson et al. (2004) show that satisfied customers are more loyal, which decreases a firm's risk by reducing the volatility of demand. In less uncertain conditions, firms can better generate value, as captured by Tobin's qthe ratio of a firm's market value to the current replacement cost of its assets. Mittal et al. (2005) find a connection between CS and longterm financial performance. Similar results appear in customer equity literature (e.g., Hogan et al., 2002). However, Matzler et al. (2008) suggest that an optimal level of CS exists that generates value for shareholders, whereas beyond that level, the effect becomes negative.

This research extends the work by Matzler et al. (2008) by connecting CS and SV to explain a firm's BE and suggesting an inverted U-shaped relationship between CS and SV, which translates into an inverted U-shaped connection between CS and BE. Unlike the article by Matzler et al. (2008), this research provides theoretical arguments. That is, at high levels of CS, financial performance should suffer for two reasons. First, if a manager satisfies customers at the expense of the firm's non-customer stakeholders, the latter group will not provide valuable intangible resources, which may damage a firm's $\mathrm{BE}$ value. Second, if managers satisfy customers as well as noncustomer stakeholders, the resulting policy may represent an entrenchment strategy that a manager implements when confronted with dissatisfied shareholders (Cespa and Cestone, 2007; Surroca and Tribó, 2008). This policy likely has negative effects on performance (Morck et al., 1988), which would then translate into a reduction in BE value.

An example serves as a good illustration. When Coca-Cola tried to change the flavor of its Coke brand in 1985, customers organized pressure groups to agitate against such a change. The mass media supported these protesting customers, noting that Coke represented an icon of the American way of life. Finally, the CEO of Coca-Cola, Roberto Goizueta, decided to maintain both Classic Coke and New Coke, which entailed a costly decision and led to a major marketing flop that should have cost Goizueta his post. However, he retained his position as CEO by justifying the move on the basis of an attempt to increase CS. In this example, Goizueta used CS as an entrenchment mechanism in response to dissatisfied shareholders, who suffered because of the expensive policy of doubling the number of Coca-Cola products despite their minimal differentiation (Friedman, 1992). In the long term, the Coca-Cola brand benefited from this policy, perhaps because significant CS (above the mean), though not too great (less than the last quartile of the distribution), has a negative effect on financial performance but an overall positive effect on BE. Section 4 provides details supporting this explanation.

To confirm the proposed theoretical contention, this study undertakes an empirical analysis of an international database composed of 69 firms from 11 nations during the period 2002-2005. The results indicate that CS has a positive effect on BE for small to medium values of the distribution, but for large values (i.e., last quartile of the distribution), the effect becomes negative. Hence, the findings offer a clear recommendation: A manager aiming to improve a firm's BE value cannot implement marketing tools focused solely on satisfying customers without considering the effects on shareholders and noncustomer stakeholders.
The remainder of this article proceeds as follows: Section 2 summarizes the relevant literature related to the objectives of this work and develops the hypotheses. Section 3 presents the research method including a description of the sample, variables and empirical models. The empirical results appear in Section 4. Section 5 provides a simulation. The final section of this article covers the main conclusions of the research and discusses their importance.

\section{Theoretical framework}

The proposed model establishes a partial mediation by SV in the connection from CS to BE. This partial mediation indicates that CS directly affects BE but also indirectly affects BE through the influence on SV, as Fig. 1 shows.

\subsection{Impact of customer satisfaction on shareholder value}

Early research justifies the connection from CS to SV, according to several arguments. First, satisfied customers are more loyal, less sensitive to price movements, and more likely to engage in positive word-of mouth behaviors (Anderson et al., 2004; Brady and Robertson, 2001; Matzler et al., 2008). Thus, the firm experiences less volatility and risk associated with present and anticipated cash flows (Anderson and Sullivan, 1993; Berger et al., 2006; Gruca and Rego, 2005; Hogan et al., 2002; Luo and Bhattacharya, 2006; Mittal et al., 2005). Lower volatility facilitates investment decisions that maximize a firm's value. Second, loyal, satisfied customers increase the firm's bargaining power with other stakeholders, such as suppliers, and enable the firm to demand specific investments that generate lower costs and risk, faster market penetration, and improve financial results (Anderson et al., 2004).

However, beyond certain levels, CS may exert a negative impact on SV. Firms whose managers focus mainly on satisfying customers may lose their competitive advantage because they neglect the interests of other stakeholders, to the detriment of their financial results (Luk et al., 2005). Even if satisfaction ranks high among both customers and non-customer stakeholders, the strategy may appear to be an entrenchment policy that a manager adopts in order to protect his or her private benefits, which could erode profits. Such a strategy enables the manager to canvass support from customers as a shield against any disciplinary pressures from shareholders. Morgan et al. (2005) argue that powerful customers may make managers particularly aware of their interests, in which case the manager may gain a reinforced position with regard to shareholders. For example, NetworkCo, a data scanning company, established a separate unit and a formal system to track the CS of its 12 largest customers given that these customers accounted for the majority of the firm's revenue (Morgan et al., 2005). Hence, the satisfaction of these customers substantially reinforces the managerial position in the firm. Pagano and Volpin (2005) use a similar argument applied to employees and suggest that firms offer long-term labor contracts to improve employee satisfaction and thereby deter takeover threats. When they experience less pressure from financial markets, managers have fewer incentives to generate SV and more incentives to pursue their own private benefits. Moreover, managers can disguise a decrease in profits, which is actually due to private benefit extraction, as a consequence of implementing a policy aimed at satisfying customers.

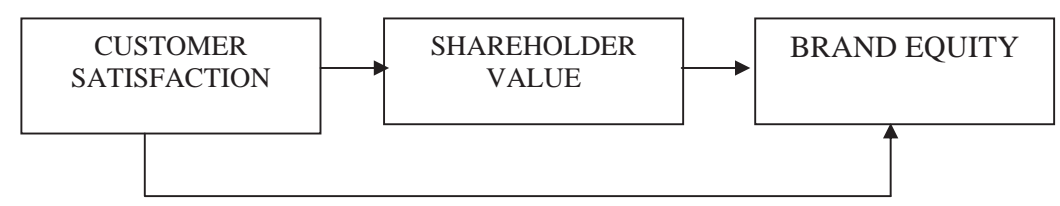

Fig. 1. Model. 
Hypothesis 1. Customer satisfaction has a positive impact on shareholder value up to a certain level, beyond which the effect is negative.

The proposed relationship between CS and SV is consistent with Matzler et al. (2008), although these authors neither provide a theoretical justification nor consider endogeneity concerns, and they focus solely on the United States. This study addresses these gaps and integrates the analysis of the CS and SV relationship in the connection from CS to BE through SV. Also, the study recognizes that shareholder value may influence CS (McGuire et al., 1988; Waddock and Graves, 1997), which becomes important because estimating the effect of CS on SV will require addressing reverse causality concerns.

\subsection{Connecting customer satisfaction to brand equity}

Customer satisfaction may influence BE through one direct and one indirect (through SV) channel. Remarkably, BE measures can include customer mind-set, as well as product market and financial market outputs related to brands (Ailawadi et al., 2003).

The direct channel. Some authors suggest a positive connection between CS and BE (Aaker, 1992; Anderson and Sullivan, 1993; Blackston, 2000; Keller, 1993). Companies consider improved CS as being a principal strategy for gaining loyalty, improving willingness to pay, and enhancing the lifetime value of the customer to the firm (i.e., customer equity, Keller and Lehmann, 2006; Hogan et al., 2002). The more loyal the firm's customers, the less vulnerable that firm is to competitive pressures, so managers can implement successful valuegenerating strategies generating BE value (Anderson and Sullivan, 1993). In addition, CS represents a major component of the broader concept of a firm's CSP that, according to instrumental stakeholder theory (Donaldson and Preston, 1995; Jones, 1995), generates value. By behaving responsibly, firms can obtain continued support from stakeholders and access to valuable resources, which contribute to the creation of favorable, strong, unique brand associations (Keller, 1993, 2003) and improve brand knowledge and thus BE. Blackston (2000) also states that consumers are active participants in the creation of BE. Therefore, a positive direct effect should move from CS to a firm's BE.

The indirect channel connecting CS to BE through SV. On the one hand, according to Hypothesis 1, CS has a dual effect on SV, with opposite signs, such that the effect is positive for normal values of CS but negative for larger ones. On the other hand, a natural positive connection exists between SV and BE, because SV facilitates investments in intangible assets (i.e., slack resources hypothesis; Waddock and Graves, 1997), such as corporate social responsibility, advertising, and research and development. Such intangible investments have positive effects on brands (Mühlbacher et al., 2006) and improve BE. Simon and Sullivan (1993) argue that Tobin's q (the natural instrument for measuring SV) and the firm's BE relate positively. Therefore, Hypothesis 1 and the expected positive connection between SV and BE imply that the indirect channel suggests a negative impact of $\mathrm{CS}$ on $\mathrm{BE}$, through reductions in $\mathrm{SV}$, for larger values of CS.

In comparing the arguments in support of the positive direct effect, which rely on customer equity and instrumental stakeholder theory, versus those that explain the negative indirect effect for large values of $\mathrm{CS}$, which reflect managerial entrenchment theory, the resulting expectation involves a positive effect on $\mathrm{BE}$ for normal values of CS but a negative effect for extreme CS values. Note that the marginal impact of CS on customer loyalty becomes lower as CS increases. That is, an increase in satisfaction for already highly satisfied customers has barely any effect on loyalty, but this increase also signals managerial entrenchment, which substantially damages SV and therefore BE.

Finally, consistent with the claim of a positive direct effect of CS on $\mathrm{BE}$, the overall negative effect of CS on BE for extreme CS values may be less negative than that of CS on SV. This statement implies that the threshold value above which the overall effect of CS on BE becomes negative should be greater than the threshold at which CS begins to have a negative impact on SV (see Fig. 3 in Section 5). These arguments lead to the following hypothesis:

Hypothesis 2. Customer satisfaction has a direct effect on brand equity but also a negative indirect effect, resulting from reductions in shareholder value, at greater values. The overall effect is positive in normal conditions and becomes negative only at extreme values of customer satisfaction.

In summary, SV partially mediates the connection from $\mathrm{CS}$ to $\mathrm{BE}$, and this partial mediation is positive (negative) for normal (extreme) values of CS. The final proposed model appears in Fig. 2.

\section{Empirical analysis}

\subsection{Sample and data}

The sample consists of three cross-listed databases. The first database, OSIRIS, contains standardized balance sheet information and thereby accommodates the wide variety of financial accounting practices across countries and industries. The second database, SiRi, is a product of Sustainable Investment Research International Company, the world's largest company specializing in socially responsible investments (www.siricompany.com). Finally, the third database, Interbrand (http://www.interbrand.com/surveys.asp), provides information about the $\mathrm{BE}$ of the 100 most valuable brands. The final sample consists of panel data pertaining to 69 non-financial companies from 11 countries for the period 2002-2005 with a total number of 105 observations containing information of all variables used in the specifications to contrast. The reduction from 100 brands to 69 firms is due to four reasons. First, the exclusion of brands belongs to a conglomerate in which the information of other brands is not available (10 observations). Note that data on CS correspond to the overall conglomerate. Hence, the satisfaction of customers at the conglomerate level does not ensure a homogeneous satisfaction of customers in all brands of the organization, and so the relationships between CS and BE would have been spurious for these observations. Second, two brand observations of a conglomerate are aggregated in a single one. Third, the sample does not contain financial firms (12 observations). Such exclusion is standard practice in studies of social responsibility and financial performance (e.g. Griffin and Mahon, 1997; Russo and Fouts, 1997; Villalonga, 2004) given that the drivers of CS for these industries are different from those in manufacturing and other service industries (Krishnan et al., 1999). Last, 8 firms do not provide information on the ownership structure. In summary, the exclusion of the previous 31 observations provides further robustness to the results by eliminating spurious correlations as well as potential outliers explaining the relationship between CS and BE.

The caveat may be a concern on sample selection bias. However, a reestimation including financial firms does not significantly alter the results (available upon request). Additionally, a reestimation of the specifications using the subsample of firms with BE values below the median, given that the initial sample is composed of the most valuable brands, leads to quite consistent results with those for the overall sample (available upon request). Hence, sample selection bias does not appear to be a significant concern.

\subsection{Variables}

Table 1 lists the definitions of the variables in the empirical analysis. The main dependent variable is brand equity, measured with the Interbrand score. Interbrand's method for valuing brands consists of three analyses: financial, role of brand, and brand strength. 


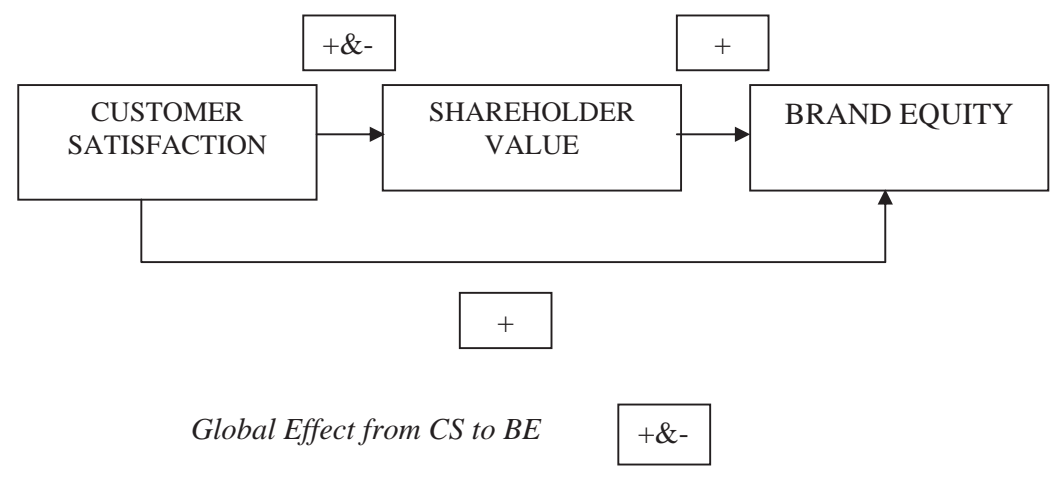

Fig. 2. Model estimation.

Financial analysis forecasts current and future revenues attributed to the branded products, subtracting the costs of doing business (e.g., operating costs and taxes) and intangibles, such as patents and management strength, to assess the portion of earnings due to the brand. The role of the brand constitutes a measure of how the brand influences customer demand at the point of purchase. Finally, brand strength provides a benchmark of the brand's ability to secure ongoing customer demand (loyalty, repurchase, and retention) and sustain future earnings, which translates branded earnings into net present value. This assessment provides a structured way to determine specific risks to brand strength. Keller and Lehmann (2006) divide existing measures of BE into three categories: customer mind-set, product market and financial market outcomes.

The measure for this study integrates product market and financial market outcomes, which, according to Ailawadi et al. (2003), is more "complete" than a single-category measure. The Interbrand measure addresses criticisms concerning the lack of objectivity in BE measures based exclusively on customer mind-set, such as the one Millward Brown uses (Ailawadi et al., 2003). Madden et al. (2006) defend the use of Interbrand data as the most well-known and widely used brand valuation method (Haigh and Perrier, 1997).

The second dependent variable is shareholder value, measured through Tobin's q (i.e., market-to-book ratio value of equity), which captures future growth expectations (Anderson et al., 2004).

For the explanatory variable, customer satisfaction, SiRi provides a score that equals the normalized weighted average of the following items: (1) whether a separate report features customer issues; (2) the appearance of information concerning customer issues on the firm's Web site; (3) whether the annual report contains information concerning customer issues; (4) a formal policy statement noting customer issues; (5) the degree of detail of the management system, including the disclosure of quantitative data and the existence of a formal policy with regard to product quality; (6) whether a formal policy pertains to marketing/advertising practices; (7) the existence of a formal policy statement on product safety; (8) the level of board responsibility for CS; (9) facilities with quality certification; and (10) marketing practices designed to satisfy customers. The SiRi specialists assign weights at a sector level, according to the damage to customers' interests when a firm does not satisfy a specific item.

Finally, this research uses several control variables. "Other stakeholder satisfaction" refers to the SiRi score for a firm's overall corporate social responsibility, less the effect due to customers and shareholders, which are subject to separate investigations. Including this variable eliminates the spurious negative effect so that increases in CS may influence other stakeholders' satisfaction, which in turn may affect performance and $\mathrm{BE}$ value. Leverage is the debt-to-equity ratio. Existing literature (Roberts, 1992; Waddock and Graves, 1997) shows that this variable represents a traditional determinant of performance and value generation (Leland, 1998). Size is the number of employees on a log scale. Size may affect a firm's visibility and performance, as well as the BE value (Ullman, 1985). The RED intensity measure equals the ratio of R\&D investments to the number of employees. This variable may affect a firm's technology development and thus growth (Chauvin and Hirschey, 1993). Simon and Sullivan (1993) also consider R\&D intensity an important potential determinant of $\mathrm{BE}$ when technological innovation is critical to consumers. Finally, the specification includes temporal, sectoral, and country dummies.

\subsection{Method}

The following specification tests Hypothesis 1, regarding the connection from CS to SV:

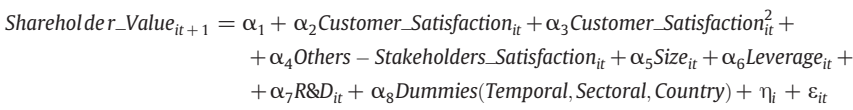

where $\eta_{i}$ is the firm-specific component of the error term, and $\varepsilon_{i t}$ is the error term. Testing for the possible negative effect of CS on SV at larger values requires including a quadratic term of Customer Satisfaction in the specification. That is, Hypothesis 1 receives support if $\alpha_{2}>0$ and $\alpha_{3}<0$.

The test for Hypothesis 2 employs a specification that features the firm's BE as the dependent variable and CS and SV, as well as different controls, as the explanatory variables:

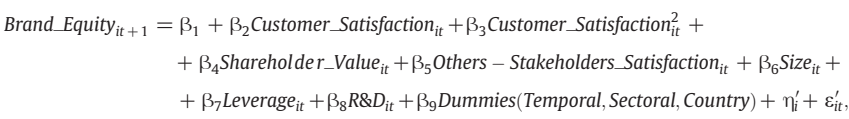

where $\eta_{i}^{\prime}$ is the firm-specific component of the error term, and $\varepsilon_{i t}^{\prime}$ is the error term.

These specifications suffer two potential endogenous problems. First, a correlation might exist between unobservable heterogeneity $\eta_{i}$ and the explanatory variables (fixed-effect problem). If Hausman tests reveal this issue, fixed-effect estimations can address it. Second, in specification (1), SV may have an impact on CS (McGuire et al., 1988; Waddock and Graves, 1997). To address this endogeneity concern (reverse causality), the analysis relies on a dependent variable led by one period, as well as an instrument of CS (see Wooldridge, 2008). The instrument is the predicted value obtained from an estimation of CS in terms of the control variables (Size, Leverage, and R\&D). The adoption of such specification follows Hirons and Simon (1998) and Athanassopoulos (2000) for R\&D; Fornell et al. (2006) for risk (related to firm's leverage); and Ullman (1985) for size, which is a proxy of firm's visibility. The previous factors also affect the expectation of future CS, which is a main driver of current CS 
Table 1

Definition of the variables.

\begin{tabular}{|c|c|}
\hline \multicolumn{2}{|l|}{ Dependent variables } \\
\hline Brand_Equity & $\begin{array}{l}\text { The score that Interbrand provides for such issue. Interbrand's method of valuing brands consists of three analyses: } \\
\text { financial, role of brand, and brand strength. The financial analysis forecasts current and future revenues attributed } \\
\text { to the branded products, subtracting the costs of doing business (e.g., operating costs, taxes) and intangibles, such } \\
\text { as patents and management strength, to assess the portion of earnings due to the brand. The role of the brand } \\
\text { constitutes a measure of how the brand influences customer demand at the point of purchase. Finally, brand strength } \\
\text { provides a benchmark of the brand's ability to secure ongoing customer demand (loyalty, repurchase, and retention) } \\
\text { and sustain future earnings, which translates branded earnings into net present value. This assessment provides a } \\
\text { structured means to determine specific risks to the strength of the brands. }\end{array}$ \\
\hline Shareholder_Value & Tobin's q, which is approached through the market-to-book ratio (market value of equity to book value of equity). \\
\hline \multicolumn{2}{|l|}{ Main explanatory variables } \\
\hline Customer_Satisfaction & $\begin{array}{l}\text { Customer Satisfaction through the score that SiRi provides in this issue, which is the weighted average of the following } \\
\text { items: (1) whether a separate report features customer issues; (2) the appearance of information concerning customer } \\
\text { issues on the firm's Web site; (3) whether the annual report contains information concerning customer issues; (4) a } \\
\text { formal policy statement noting customer issues; (5) the degree of detail of the management system, including the } \\
\text { disclosure of quantitative data and the existence of a formal policy with regard to product quality; (6) whether a formal } \\
\text { policy pertains to marketing/advertising practices; (7) the existence of a formal policy statement on product safety; } \\
\text { (8) the level of board responsibility for customer satisfaction; (9) facilities with quality certification; and (10) marketing } \\
\text { practices designed to satisfy customers. }\end{array}$ \\
\hline Ownership_Concentration & The stake of the main blockholder (instrument of Shareholder Value) \\
\hline \multicolumn{2}{|l|}{ Control variables } \\
\hline Other-Stakeholders_Satisfaction & The SiRi score of a firm's overall CSR, less the effect due to customers and shareholders \\
\hline Leverage & The debt-to-equity ratio \\
\hline Size & Number of employees on a log scale \\
\hline$R \& D$ & The ratio of R\&D investments to the number of employees. \\
\hline
\end{tabular}

(Anderson and Sullivan, 1993). Additionally, Tables 3 and 4 report the result of conducting underidentification tests to estimate whether the instruments proposed are correlated with the endogenous variables (Bascle, 2008). All instruments pass the test indicating that they are strong instruments.

Similar to specification (1), specification (2), may also entail the problem of reverse causality, given that the measure of BE relies on financial performance. Firms with better brands enjoy better financing conditions and thus better performance and improved SV. To address this problem, the analysis proceeds in two ways. First, the dependent variable (BE) is led by one period. Second, "ownership concentration" (OC), defined as the stake of the main blockholder, provides an instrument of SV. This variable is a good instrument because the stake of the main blockholder relates to a firm's performance (Demsetz and Villalonga, 2001) but less closely to the value of intangible assets (BE).

\section{Results}

The descriptive evidence in Table 2 reveals that the firms in the sample reach a median Tobin's q (Shareholder_Value) value of 3.4 and profitability (return on assets) greater than $5 \%$. The median value of Customer_Satisfaction is around the midpoint .5. The firms display significant BE values (median value of 7440 million $€$ ). Thus, firms in the sample achieve good financial conditions, which makes a negative

Table 2

Descriptive statistics.

\begin{tabular}{llcrrr}
\hline Variable & Observ. & Median & \multicolumn{1}{l}{ Std. } & Minimum & Maximum \\
\hline Brand_Equity & 105 & 7440 & $15,207.62$ & 592.06 & $70,453.00$ \\
Shareholder_Value & 105 & 3.1 & 17.54 & 0.54 & 35.55 \\
Customer_Satisfaction & 105 & 0.5 & 0.17 & 0.00 & 1.00 \\
Other-Stakehold._Satisf. & 105 & 0.5 & 0.14 & 0.07 & 0.73 \\
Leverage & 105 & 1.7 & 6.58 & 0.02 & 51.81 \\
Size & 105 & 11.4 & 1.22 & 7.51 & 12.99 \\
ROA (\%) & 105 & 5.2 & 10.73 & -8.22 & 21.01 \\
R\&D & 105 & 0.42 & 22.59 & 0.00 & 113.49 \\
\hline
\end{tabular}

connection among CS, SV, and BE less likely and enhances the robustness of the results.

Table 3 shows the impact of CS on SV. The satisfied customers variable has a positive impact on SV (Tobin's q), though Column 3 reveals that for large values of $\mathrm{CS}$, the effect on SV is negative. Specifically, the threshold above which CS has a negative impact is .55 ( - coefficient $\mathrm{CS} /\left[2 \times\right.$ coefficient of $\left.\left.\mathrm{CS}^{2}\right]=.181 / 2 \times .166=.55\right)$. In addition, the median value of CS is .5 (see Table 2), which means that firms that focus intensively on satisfying their customers damage their growth expectations (Tobin's q) and SV. This result conforms to Hypothesis 1. The concave effect of CS on SV holds even when the specification includes the Other-Stakeholders_Satisfaction variable. Hence, the relationship between CS and SV is not spurious or based on their mutual connection to the satisfaction of non-customer stakeholders. That is, regardless of the effect of other stakeholders on a firm's performance, large values of CS have a negative impact on SV.

Table 4 summarizes the test of the connection from CS to BE and its possible mediation by SV. In Column 1, CS has an overall positive effect on $\mathrm{BE}$ (coefficient .522, $p<.01$ ), but the inclusion of the quadratic term (Column 2) demonstrates that the effect of CS on BE is negative for values of CS greater than .65 (this value is the result of - coefficient of $\mathrm{CS} /\left[2 \times\right.$ coefficient of $\left.\left.\mathrm{CS}^{2}\right]=.503 /(2 \times .386)=.65\right)$. That is, for large values of CS (greater than the threshold that defines the last quartile of the CS distribution, or .63), the overall effect of CS on BE is negative. This threshold (.65) is higher than that for SV (.55), because the overall effect of CS on BE incorporates the direct effect between both variables, which is positive (coefficient .549, $p<.01$ in column 3).

Therefore, in the interval of .55-.65, or roughly near the last quartile of the CS distribution, improvements in CS have a negative effect on financial performance but not on BE. Beyond the threshold that defines the last quartile, the effect is also negative for $\mathrm{BE}$, in support of Hypothesis 2. Column 3 also decomposes the direct and indirect effects of CS on BE through SV-because including SV eliminates its indirect effect-and reveals that the direct effect of CS on BE is also positive (coefficient .250, $p=0.051$ ), in support of Hypothesis 2 . The SV variable (instrumented through the variable of 
Table 3

Determinants of shareholder's value.

\begin{tabular}{|c|c|c|c|}
\hline Dependent variable & $\begin{array}{l}\text { Shareholder_Value (Tobin's q) } \\
\text { led by one period }\end{array}$ & $\begin{array}{l}\text { Shareholder_Value (Tobin's q) } \\
\text { (instrumenting Customer_Satisfaction) }\end{array}$ & $\begin{array}{l}\text { Shareholder_Value (Tobin's q) } \\
\text { (instrumenting Customer_Satisfaction) }\end{array}$ \\
\hline Customer_Satisfaction & $\begin{array}{l}0.128^{* *} \\
(0.011)\end{array}$ & $\begin{array}{l}0.190^{* *} \\
(0.082)\end{array}$ & $\begin{array}{l}0.181^{* * *} \\
(0.064)\end{array}$ \\
\hline Customer_Satisfaction $^{2}$ & & & $\begin{array}{l}-0.166^{* * *} \\
(0.058)\end{array}$ \\
\hline Other Stakeholders_Satisfaction & $\begin{array}{l}-0.035^{* *} \\
(0.013)\end{array}$ & $\begin{array}{l}0.011^{*} \\
(0.007)\end{array}$ & $\begin{array}{l}0.001 \\
(0.002)\end{array}$ \\
\hline Leverage & $\begin{array}{l}-0.005 \\
(0.009)\end{array}$ & $\begin{array}{l}-0.007 \\
(0.007)\end{array}$ & $\begin{array}{l}0.008^{* * *} \\
(0.001)\end{array}$ \\
\hline Size & $\begin{array}{l}0.055^{* * *} \\
(0.014)\end{array}$ & $\begin{array}{l}0.152^{* *} \\
(0.070)\end{array}$ & $\begin{array}{l}-0.002 \\
(0.002)\end{array}$ \\
\hline$R \& D$ & $\begin{array}{l}0.003 \\
(0.011)\end{array}$ & $\begin{array}{l}0.034 \\
(0.045)\end{array}$ & $\begin{array}{l}0.002 \\
(0.002)\end{array}$ \\
\hline Intercept & $\begin{array}{l}0.534^{* * *} \\
(0.040)\end{array}$ & $\begin{array}{l}0.540^{* * *} \\
(0.022)\end{array}$ & $\begin{array}{l}-0.015 \\
(0.013)\end{array}$ \\
\hline Number of observations & 105 & 105 & 105 \\
\hline$R^{2}(\%)$ & 19.38 & 56.24 & 63.74 \\
\hline Weak instrument test & & $19.712(0.000)$ & $12.613(0.004)$ \\
\hline Fitness test & $37.23(0.000)$ & $47.44(0.000)$ & $57.01(0.000)$ \\
\hline Hausman test & $14.69(0.100)$ & $22.32(0.010)$ & $16.77(0.110)$ \\
\hline Type of estimation & Random effects & Fixed effects & Random effects \\
\hline
\end{tabular}

${ }^{* * *} p$-value $.01,{ }^{* *} p$-value $.05,{ }^{*} p$-value .10 .

Notes: Table 1 shows the definitions of the variables. Standard deviations in parentheses. The Wald test is fitness test. Fixed-effect estimation (Column 2 ) uses the F-test as the fitness test. The weak instrument test is the Anderson Canon Correlation test (Bascle, 2008). This test fixes as a null hypothesis that the equation is underidentified. This test is distributed as Chi-square $(\mathrm{L}-\mathrm{k}+1)$, with $\mathrm{L}$ being the number of excluded instruments and $\mathrm{k}$ the number of endogenous regressors. A rejection of the null hypothesis means that the instruments are strong (correlated with the endogenous variable).

ownership_concentration) has a significant, positive impact on BE, which, in combination with the positive direct effect of CS on BE, indicates that SV plays a partial mediating role in the connection from CS to BE. Note that CS also has a direct effect on SV (see Table 3), in support of the SV mediation. That is, SV mediates the indirect connection from CS to $\mathrm{BE}$, while the direct connection from CS to $\mathrm{BE}$ does not rely on $\mathrm{SV}$, which indicates that $\mathrm{SV}$ mediation is only partial.

The control variables have several effects; in particular, R\&D is a strong positive determinant of a firm's BE, and levered firms enjoy higher BE values. Debt constrains managers from behaving opportunistically, which eventually increases the firm's BE value. The non- significant coefficient of other stakeholders' satisfaction indicates that the effect of CS on BE is not spurious, according to the connections of CS to other-stakeholders_satisfaction and from this latter variable to BE.

Finally, the investigation of the effect of non-customer stakeholders' satisfaction on $\mathrm{BE}$, which includes the quadratic values of the former variable, reveals that such variable is not neutral but also has an inverted U-shaped relationship with SV (available upon request). In particular, the linear term is positive (coefficient $.837, p=.020$ ), but the quadratic term is negative (coefficient $-.693, p=.020$ ). This evidence is consistent with the entrenchment argument; extreme

Table 4

Determinants of brand equity.

\begin{tabular}{|c|c|c|c|}
\hline Dependent variable & $\begin{array}{l}\text { Brand_Equity } \\
\text { (one-period lead) }\end{array}$ & $\begin{array}{l}\text { Brand_Equity } \\
\text { (one-period lead) }\end{array}$ & $\begin{array}{l}\text { Brand_Equity } \\
\text { (one-period lead) }\end{array}$ \\
\hline Customer_Satisfaction & $\begin{array}{l}0.522^{* * *} \\
(0.111)\end{array}$ & $\begin{array}{l}0.503^{* * *} \\
(0.106)\end{array}$ & $\begin{array}{l}0.250^{* *} \\
(0.138)\end{array}$ \\
\hline Customer_Satisfaction $^{2}$ & & $\begin{array}{l}-0.386^{* * *} \\
(0.129)\end{array}$ & $\begin{array}{l}-0.217 \\
(0.140)\end{array}$ \\
\hline Ownership_Concentration (instrument Tobin's q) & & & $\begin{array}{l}0.549^{* * *} \\
(0.105)\end{array}$ \\
\hline Other-Stakeholders_Satisfaction & $\begin{array}{l}0.003 \\
(0.711)\end{array}$ & $\begin{array}{l}0.002 \\
(0.007)\end{array}$ & $\begin{array}{l}0.002 \\
(0.009)\end{array}$ \\
\hline Leverage & $\begin{array}{l}0.043^{* * *} \\
(0.008)\end{array}$ & $\begin{array}{l}0.052^{* * *} \\
(0.009)\end{array}$ & $\begin{array}{l}0.016^{* * *} \\
(0.006)\end{array}$ \\
\hline Size & $\begin{array}{l}0.126^{* *} \\
(0.070)\end{array}$ & $\begin{array}{l}0.127^{*} \\
(0.073)\end{array}$ & $\begin{array}{l}0.082 \\
(0.071)\end{array}$ \\
\hline $\mathrm{R} \& \mathrm{D}$ & $\begin{array}{l}0.221^{* * *} \\
(0.055)\end{array}$ & $\begin{array}{l}0.208^{* * *} \\
(0.054)\end{array}$ & $\begin{array}{l}0.208^{* * *} \\
(0.053)\end{array}$ \\
\hline Intercept & $\begin{array}{l}-0.327 \\
(0.403)\end{array}$ & $\begin{array}{l}-0.911 \\
(1.164)\end{array}$ & $\begin{array}{l}0.480 \\
(0.836)\end{array}$ \\
\hline Number of observations & 105 & 105 & 105 \\
\hline$R^{2}(\%)$ & 77.57 & 79.35 & 82.88 \\
\hline Weak instrument test & & & $3.817(0.005)$ \\
\hline Fitness test (Wald test) & $75.88(0.000)$ & $89.10(0.000)$ & $95.79(0.000)$ \\
\hline Hausman test & $4.960(0.838)$ & $5.400(0.798)$ & $3.54(0.990)$ \\
\hline Type of estimation & Random effects & Random effects & Random effects \\
\hline
\end{tabular}

${ }^{* * *} p$-value $.01,{ }^{* *} p$-value $.05,{ }^{*} p$-value .10 .

Notes: Table 1 shows the definitions of the variables. Standard deviations in parentheses. The Wald test is the fitness test. The weak instrument test is the Anderson Canon Correlation test (Bascle, 2008). Such test fixes as a null hypothesis that the equation is underidentified. This test is distributed as Chi-square ( $\mathrm{L}-\mathrm{k}+1$ ), with $\mathrm{L}$ being the number of excluded instruments and $\mathrm{k}$ the number of endogenous regressors. A rejection of the null hypothesis means that the instruments are strong (correlated with the endogenous variable). 
degrees of customer (greater than 63.7\%) and/or non-customer satisfaction (greater than $60.4 \%=.837 / 2 \times .693$ ) may provide managers with a reinforcing mechanism to combat shareholder initiatives when BE erodes.

In addition, this study estimates other stakeholders' satisfaction (led by one period) in terms of CS, the quadratic term $\mathrm{CS}^{2}$, financial performance, and the controls from the first specification (available upon request). The result shows that both $\mathrm{CS}$ and $\mathrm{CS}^{2}$ are significant (.238, $\mathrm{p}=.005 ; .212, \mathrm{p}=.017$, respectively) explanatory variables of Other-Stakeholders_Satisfaction. That is, greater CS has a positive impact on non-customer stakeholders' interests, particularly in the region where CS has a larger value (positive and significant coefficient of $\mathrm{CS}^{2}$ ). This result is also consistent with the entrenchment hypothesis; that is, complementing CS with other stakeholders' interests provides a means for managers to reinforce their positions.

\section{Simulation}

For a clearer measure of the relevance of the effects found in the estimations, Fig. 3 offers two graphical representations relating CS to (1) shareholder value, (2) brand equity. The values of CS range between 0 and 1 , whereas the remaining variables in the specifications remain fixed at their mean levels, while the intercept is normalized to ensure the same values of SV and BE for $\mathrm{CS}=0$ for the sake of comparability. The results show an inverted U-shaped relationship in all cases, such that the maximum SV curve occurs at a lower value of CS (55\%) in comparison with $\mathrm{BE}(67 \%)$. Moreover, $\mathrm{BE}$ is more sensitive to changes in CS than SV, which is not surprising since $\mathrm{BE}$ explicitly recognizes customer loyalty in its definition, which is responsible for the direct connection of $\mathrm{BE}$ to $\mathrm{CS}$.

\section{Discussion and conclusion}

This study recognizes that the brand equity (BE) of a firm depends largely on the degree of customer satisfaction (CS), as well as on shareholder value (SV). Theoretical underpinnings suggest a close relationship between both dimensions, such that a manager who wishes to improve a firm's BE value should take both factors into consideration and not focus solely on customer-targeted marketing policies, which may have a negative effect. This result represents an important finding. CS has a direct positive effect on a firm's BE, but an indirect negative influence through reductions in SV. In other words, SV partially mediates the connection from CS to BE-positive for normal, and negative for large values of CS.

This result may reflect the implementation of an entrenchment strategy, which managers use to satisfy customers' interests, especially when they are concentrated and have substantial power

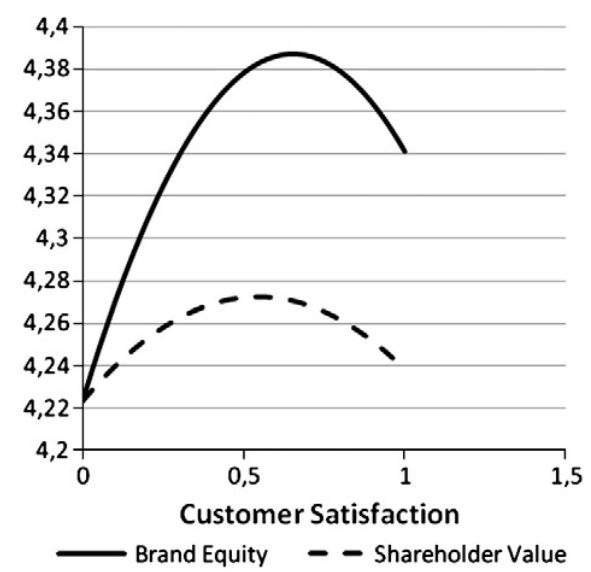

Fig. 3. Simulations of brand equity and shareholder value in terms of customer satisfaction.
(Morgan et al., 2005), and counteract the actions of unsatisfied shareholders. This resource-consuming strategy has negative effects on performance, which eventually damage the firm's BE.

The database that provides the information for this research contains details concerning socially responsible investments, $\mathrm{BE}$, and standardized balance sheets. The results from this combined database indicate that improving CS beyond the last quartile of the distribution has a negative effect on a firm's BE.

This finding in turn has important implications. Managers should not focus solely on one stakeholder (i.e., customers) but take a wider perspective and consider other stakeholders, as well as shareholders, to define a successful BE value strategy. Luk et al. (2005) and Morgan et al. (2005) warn of the negative effects of extremely customeroriented policies. Furthermore, firms cannot sustain such policies over time because of the perverse effects they have on financial performance, as well as on brand image. Conversely, investors that observe the firm's excessive concern with the relationship with its customers should be aware that such behavior may signal managerial entrenchment, which will erode financial results and brand image over time.

Some of the limitations of this article offer suggestions for further research. First, the limited number of observations prevents a higherlevel exploration of the international features of the data or a comparison of different institutional frameworks (e.g., Anglo-Saxon versus non-Anglo-Saxon countries). This data limitation also precludes an analysis by sectors, which might address whether the perverse effects of high values of CS on BE may be more or less pronounced in more customer-concentrated sectors. The sample also suffers from sample selection bias, because information about BE is available only for corporations with higher BE values. However, this factor provides additional robustness to the results, because the entrenchment motive should be yet more evident in firms with lower $B E$ value. In such corporations, visibility and control mechanisms are lesser, and so managerial entrenchment should be more likely. The negative effect of CS on BE might therefore occur even at low values, not just in the upper quartile of the distribution. This topic remains open for future research.

\section{Acknowledgments}

The authors thank Carlos Bendito, Managing Director of Analistas Internacionales en Sostenibilidad (AISTM), Vicente Cuñat, the referees and the Editor as well as the participants at The Thought Leaders International Conference on Brand Management (Birmingham, 2007) for their helpful comments. The authors also acknowledge financial support from the Spanish Ministerio de Ciencia y Tecnologia (grants \# SEJ2006-09401, SEJ2006-14098, and SEJ2007-65897) and Comunidad de Madrid (grants \#2008/00037/001 and \#2009/00138/001).

\section{References}

Aaker DA. The value of brand equity. J Bus Strategy 1992;13:27-32 (July/August).

Ailawadi KL, Lehmann DR, Neslin SA. Revenue premium as an outcome measure of brand equity. J Mark 2003;67:1-17 (October).

Anderson PF. Marketing, strategic planning and the theory of the firm. J Mark 1982;46 (2): $15-26$.

Anderson EW, Sullivan M. The antecedents and consequences of customer satisfaction for firms. Mark Sci 1993;12:125-43.

Anderson EW, Fornell C, Mazvancheryl SK. Customer satisfaction and shareholder value. J Mark 2004;68:172-85.

Athanassopoulos AD. Customer satisfaction cues to support market segmentation and explain switching behavior. J Bus Res 2000;47(3):191-207.

Aupperle KE. An empirical measure of corporate social orientation. Res Corp Soc Perform Policy 1984;6:27-54.

Bascle G. Controlling for endogeneity with instrumental variables in strategic management. Strateg Organ 2008;6:285-327, doi:10.1177/1476127008094339.

Berger PD, Eechambadi N, George M, Lehmann DR, Rizley R, Venkatesan R. From customer lifetime value to shareholder value. J Serv Res 2006;9(2):156-67.

Blackston M. Observations: building brand equity by managing the brand's relationship. J Advert Res 2000;40:101-5. 
Blumenthal D, Bergstrom AJ. Brand councils that care: towards the convergence of branding and corporate social responsibility. J Brand Manage 2003;10(4/5): 327-41.

Brady MK, Robertson CJ. Searching for a consensus on the antecedent role of service quality and satisfaction: an exploratory cross-national study. J Bus Res 2001;51(1): 53-60.

Cespa G, Cestone G. Corporate social responsibility and managerial entrenchment. J Econ Manage Strategy 2007;16(3):741-71.

Chauvin KW, Hirschey M. Advertising. R\&D expenditures and the market value of the firm. Financ Manage 1993;22(4):128-40.

Demsetz K, Villalonga B. Ownership structure and corporate performance. J Corp Finance 2001;7:209-33.

Donaldson TL, Preston LE. The stakeholder theory of the corporation: concepts, evidence, and implications. Acad Manage Rev 1995;20:65-91.

Fornell C, Mithas S, Morgeson III FV, Krishnan MS. Customer satisfaction and stock prices: high returns, low risk. J Mark 2006;70:3-14.

Friedman T. The world of the world of Coca-Cola. Commun Res 1992;19(5):642-62.

Greenlay GE, Foxall GR. External moderation of associations among stakeholder orientations and company performance. Int J Res Mark 1998;15(1):51-69.

Greenley GE, Hooley GJ, Rudd JM. Market orientation in a multiple stakeholder orientation context: implications for marketing capabilities and assets. J Bus Res 2005;58:1483-94.

Griffin JJ, Mahon JF. The corporate social performance and corporate financial performance debate. Twenty-five years of incomparable research. Bus Soc 1997;36(1):5-31.

Gruca TS, Rego LL. Customer satisfaction, cash flow, and shareholder value. J Mark 2005;69:115-30 (July)

Haigh D, Perrier R. Valuation of trademarks and brand names. In: Perrier Raymond editor. Brand valuation. 3d ed. London: Premier Books; 1997. p. 19-24.

Hirons E, Simon A. External customer satisfaction as a performance measure of the management of a research and development department. Int J Qual Reliab Manage 1998;15(8/9):969-87.

Hogan JE, Lemon KN, Rust RT. Customer equity management. Chartering new directions for future marketing. J Serv Res 2002;1:4-12 (August).

Jawahar IM, McLaughlin GL. Toward a descriptive stakeholder theory: an organizational life cycle approach. Acad Manage Rev 2001;26(3):397-414.

Jones TM. Instrumental stakeholder theory: a synthesis of ethics and economics. Acad Manage Rev 1995;20(2):404-37.

Keller KL. Conceptualizing, measuring and managing brand equity. J Mark 1993;57: 1-22 (January)

Keller KL. Brand synthesis: the multidimensionality of brand knowledge. J Consum Res 2003;20:595-600 (March).

Keller KL, Lehmann DR. Brands and branding: research findings and future priorities. Mark Sci 2006;25(6):740-59.

Kraft K, Hage J. Strategy, social responsibility and implementation. J Bus Ethics 1990;9 (1):11-9.

Krishnan MS, Ramaswamy V, Meyer MC, Damien P. Customer satisfaction for financial services: the role of products, services, and information technology. Manage Sci 1999;45(9):1194-209.

Leland HE. Agency costs, risk management, and capital structure. J Finance 1998;53(4): 1213-43, doi:10.1111/0022-1082.00051.
Luk ChL, Yau OHM, Chow RPM, Tse ACB, Sin LYM. Stakeholder orientation and business performance: the case of service companies in China. J Int Mark 2005;13(1): 89-110.

Luo X, Bhattacharya CB. Corporate social responsibility, customer satisfaction, and market value. J Mark 2006;70:1-18 (October).

Madden TJ, Fehle F, Fournier S. Brands matter: an empirical demonstration of the creation of shareholder value through branding. J Acad Mark Sci 2006;34(2): 224-35.

Matzler K, Hinterhuber HH, Daxer Ch, Huber M. The relationship between customer satisfaction and shareholder value. Total Qual Manage Bus Excell 2008;16(5): $671-80$

McGuire JB, Sundgren A, Schneeweis T. Corporate social responsibility and firm financial performance. Acad Manage J 1988;31(4):854-72.

Miller RL, Lewis WF. A stakeholder approach to marketing management using the value exchange model. Eur J Mark 1991;25(8):55-68

Mintzberg H. Power in and around organizations. Englewood Cliffs: N.J: Prentice-Hall; 1983.

Mitchell RK, Agle BR, Wood DJ. Toward a theory of stakeholder identification and salience: defining the principle of who and what really counts. Acad Manage Rev 1997;22(4):853-86.

Mittal V, Anderson EW, Sayrak A, Tadikamalla P. Dual emphasis and the long-term financial impact of customer satisfaction. Mark Sci 2005;24(4):544-55.

Morck R, Shleifer A, Vishny R. Management ownership and market valuation: an empirical analysis. J Financ Econ 1988;20(1/2):293-315.

Morgan NA, Anderson EW, Mittal V. Understanding firms' customer satisfaction information usage. J Mark 2005;69:131-51 (July).

Mühlbacher $\mathrm{H}$, Hemetsberger A, Thelen E, Vallaster CH, Massimo R, Füller J, et al. Brands as complex social phenomena. Paper presented at the Conference of Thought Leaders International Conference on Brand Management; 2006.

Pagano M, Volpin P. Managers, workers, and corporate control. J Finance 2005;60: 841-68.

Preston L, Sapienza H, Millar R. Stakeholders, stockholders, managers: who gain what from corporate governance? In: Etzioni A, Lawrence P, editors. Socio-economics: toward a new synthesis. Armonk, London: ME Sharpe; 1991. p. 149-66.

Roberts R. Determinants of corporate social responsibility disclosure: an application of stakeholder theory. Acc Organ Soc 1992;17(6):595-612.

Russo MV, Fouts PA. A resource-based perspective on corporate environmental performance and profitability. Acad Manage J 1997;40(3):534-59.

Simon CJ, Sullivan MW. The measurement and determinants of brand equity: a financia approach. Mark Sci 1993;12(1):28-52.

Surroca J, Tribó J. Managerial entrenchment and corporate social performance. J Bus Finance Acc 2008;35(5):748-89.

Ullman A. Data in search of a theory: a critical examination of the relationship among social performance, social disclosure and economic performance of U.S. firms. Acad Manage Rev 1985;10(1/2):540-57.

Villalonga B. Intangible resources, Tobin's q, and sustainability of performance differences. J Econ Behav Organ 2004;54(2):205-30.

Waddock SA, Graves SB. The corporate social performance-financial performance link Strateg Manage J 1997;18(4):303-19.

Wooldridge JM. Econometric analysis of cross section and panel data. Second edition. Cambridge; Massachusetts: The MIT Press; 2008. 